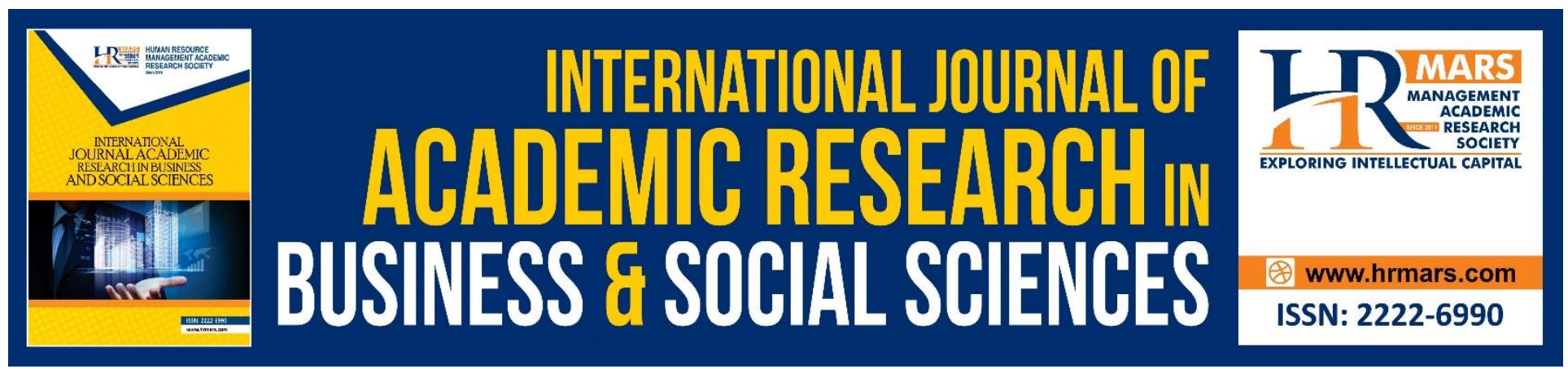

\title{
Attendance System using RFID with “Drive Thru” Techniques
}

\section{Abu Bakar Ibrahim, Che Zalina Zulkifli, Nurul Husna Abdul Kahar}

To Link this Article: http://dx.doi.org/10.6007/IJARBSS/v8-i7/4385

DOI: $\quad 10.6007 /$ IJARBSS/v8-i7/4385

Received: 24 May 2018, Revised: 21 June 2018, Accepted: 29 June 2018

Published Online: 11 July 2018

In-Text Citation: (Ibrahim, Zulkifli, \& Kahar, 2018)

To Cite this Article: Ibrahim, A. B., Zulkifli, C. Z., \& Kahar, N. H. A. (2018). Attendance System using RFID with "Drive Thru" Techniques. International Journal of Academic Research in Business and Social Sciences, 8(7), 436-444.

\section{Copyright: (c) 2018 The Author(s)}

Published by Human Resource Management Academic Research Society (www.hrmars.com)

This article is published under the Creative Commons Attribution (CC BY 4.0) license. Anyone may reproduce, distribute, translate and create derivative works of this article (for both commercial and non-commercial purposes), subject to full attribution to the original publication and authors. The full terms of this license may be seen

at: http://creativecommons.org/licences/by/4.0/legalcode

Vol. 8, No. 7, July 2018, Pg. 436 - 444

http://hrmars.com/index.php/pages/detail/IJARBSS

JOURNAL HOMEPAGE

Full Terms \& Conditions of access and use can be found at http://hrmars.com/index.php/pages/detail/publication-ethics 


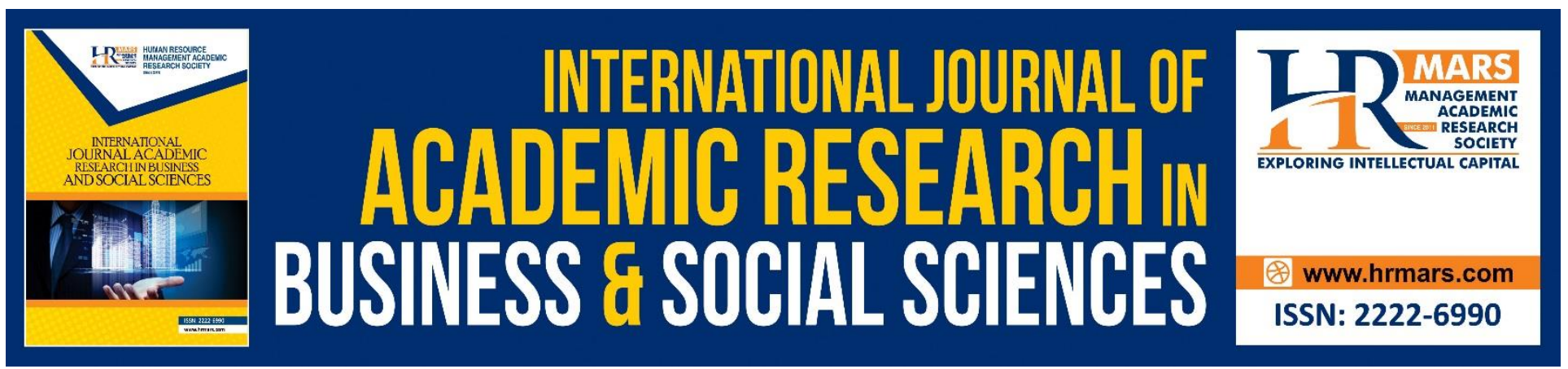

\title{
Attendance System using RFID with “Drive Thru” Techniques
}

\section{Abu Bakar Ibrahim¹, Che Zalina Zulkifli², Nurul Husna Abdul Kahar ${ }^{3}$ \\ Universiti Pendidikan Sultan Idris, Malaysia}

\begin{abstract}
The Current state of Radio Frequency Identification (RFID) has been expending in the terms of information handling and material flow. It is one of many technologies grouped under Automatic Identification such as barcodes, magnetic inks, optical character recognition, voice recognition, touch memory, smart cards, and biometrics. RFID is an important feature because of the ability to detect objects under unique identification. Therefore, a possible approach with the "Drive-Thru" Attendance System project for University Education Sultan Idris (UPSI) staff by using Radio Frequency Identification (RFID) outlines the likelihood that can be used to improve staff attendance efficiency. The purpose of this project is to improve the system of old attendance and to eliminate the remaining time during the attendance collection. The RFID reader is located at an angle called "Drive Thru Zone" on both Campuses where staff will pass the route for the purpose of scanning the identity card tag (ID) for attendance. Then, the information is processed by MTLAB and PICKIT2 before displaying the data received on the $L C D$ and the output shown on the PC / Laptop. The result shows that if the identity card is not registered, it can not access the staff attendance. About $70 \%$ of respondents agreed with the project based on the questionnaire distribution. In conclusion, "Drive Thru" shows staff arriving on time and able to eliminate the rest of the time.
\end{abstract}

Keywords: Attendance System, RFID, Drive Thru

\section{Introduction}

Radio Frequency Identification (RFID) play a big role in people daily lives. Various applications of RFID including transportation and logistics, manufacturing and processing, security, animal tagging, waste management, time and attendance, road toll management and etc. The aim of this research is to improve old attendance system that capable to eliminate time waste during manual collected attendance by create "drive-thru" attendance system. This model can be given an access badge with radio frequency identification (RFID) chip in it as its use technique of electromagnetic fields to exchange data from a tag (like a smart tag) to an object (a reader) at the post guard for the purpose of identification or tracking. Development in RFID technology widely increasing in adopting new and many features. 
INTERNATIONAL JOURNAL OF ACADEMIC RESEARCH IN BUSINESS AND SOCIAL SCIENCES Vol. 8, No. 7, July 2018, E-ISSN: 2222-6990 @ 2018 HRMARS

\section{Literature Review}

This section describes previous work down based on attendance system. Todays, lots of colleges, schools, and universities have a problem to handle large number of students and staffs especially to get their attendances. Manually, the attendance are given whenever the lecturer comes to class and pass it around for the students to tick. This manual process shows a flaws since the students can cheat and lecturer had to enter the attendance into database for record. Zatil Singhal (2012), describes the conventional method of taking attendance by calling names or signing on paper is very time consuming and insecure, hence inefficient. Krenare R. Pireva (2013) tells that counting students' absence, teachers lose couple of minutes of their classes to fill in the attendance sheet manually by calling the students for signing the documents and the worst just come after classes where there should be spent extra time for inserting the attendance data in a computer to generate the statistics and send them per email to each student and of course to the administrator and lecturer in total. Meanwhile, the staff has to queue up for a long time to punch card and put it in the slot provided according to their name which shows that both system are slow in performance and not efficient express Mr.Tushar T. Tanpure1 et. al (2013). This would cause a big problem.

Sequel to these, Arulogun O.T (2012) states that lecturers and administration in most developing countries have had to come up with ways to ensure a healthy participations from students and make sure that the students-lecturer interactive relationship is kept intact. However these strategies' are time consuming, stressful and laborious because the valuable lecture time have been used for student attendance taking and sometimes not accurate express Olatunbosun (2012). Besides that, Nurbek Saparkhojayev (2012) support the issue that universities lecturer and institution are considerable disadvantages when it comes to taking attendance since friends of absent students may write down their names and surname. This is really posing a great challenge in academic setting as the attendance is an important part of students' and staff academic record since in some institutions without a certain percentage students cannot sit for an examination tells Barroon Ismaeel Ahmad (2014). These are some of the challenges that call for an improvement as technology has advanced to provide more convenient ways in monitoring the students and staffs.

In this study we implement the Radio Frequency Identification (RFID) technology as one of figures development focuses on staffs of Universiti Pendidikan Sultan Idris (UPSI) as this university have two main campus which is Kampus Sultan Azlan Shah (KSAS) and Kampus Sultan Abdul Jalil Shah (KSAJS) a niche in educational leadership that lead to the global change. The main purpose of this research is to develop a "drive-thru" attendance system for staff UPSI by using Radio Frequency Identification (RFID). The staffs are having difficulties to punch their card as a sign of attendances due to the long distance between two main campuses which is $7.5 \mathrm{~km}$ from each other's as the staffs might have a lecture at one of the campus. Besides that, the flow of the traffics affect the time of the staffs to arrive punctually for the attendances due to the amount of vehicles on the road such as cars, buses and lorries' been using the same routes to their respective journey during peak hour for 8am lecture. The using of RFID in attendance system for staffs UPSI can improve the existing system that capable to eliminate time waste. This statement is supported by Fakolujo O. (2012) that RFID is an automated identification and data collection technology, that ensure more accurate and timely data entry and quickly gained more attentions due to current low cost and advances that open up more application area.

On the other hands, Ankita Agrawal (2013) mentions that RFID systems have been widely used in many different application areas such as; product tracking through manufacturing and assembly, control of inventory, parking lot access and control, container tracking, ID badges and access control, 
INTERNATIONAL JOURNAL OF ACADEMIC RESEARCH IN BUSINESS AND SOCIAL SCIENCES Vol. 8, No. 7, July 2018, E-ISSN: 2222-6990 @ 2018 HRMARS

equipment tracking in hospital and etc. which researcher find it is suitable to be use for taking attendances of staffs UPSI. It is one way to improve efficiency as researcher found out the parking problem on Kampus Sultan Abdul Jalil Shah (KSAJS) that is limited for the staffs. If there are any program being held on E-learning building the staffs found out the difficulties to find the parking lots and it's stressing them to punch card for the attendances. Thus, manual attendance system are very time consuming supported by Priyanka A. Sathe (2014).

\section{Methodology}

Methodology chosen to conduct this project is engineering design process. The engineering design process is an approach used in series of steps by instructional designing, building and testing for developers to create instructional course materials. This process has been adopted due to its iteration flexibility.

The definition of the problem is about the to improve old attendance system that capable to eliminate time waste compare manually collected attendance that lead to unpunctuality of the staff UPSI. This is due to the fact that current transportation infrastructure and car park facility developed are unable to cope with the influx of vehicles on the road (Leng Y.Y, et.al, 2012). This system propose better service and user friendliness and interactive.

"Drive Thru" attendance system for staff UPSI by using RFID will be created in software and hardware. In hardware, circuit included in this project is PIC 16F877A that be connected to the RFID reader RFIDIDR-232N. The ID will be stored and the tag will be detected by the reader and validation attendance will be display on the LCD display. Meanwhile, in software the system is created that analyzed uses passive RFID as a hardware because it is cheap, small in size and can communicated with Hyper Terminal to display output on PC. The attendance system contain two main components which is reader and tag. A design engineering process of attendance system by using RFID consists of two component which is hardware and software component. A flow chart of design system is shown in Figure 1. Software MTLAB Integrated Development Environment (IDE) and PIC2KIT is being used to test the communication of RFID reader as to determine either the computer can receive the ID tag that was traced by the reader for further processing. As for this project, the vehicles of staff is pass by the security guard that place the RFID reader, it will detect the frequency of the ID tag. The program will continue with combination of hardware and software where the information is send to the pc where it would display the attendance verification on the LCD. It is depends on the tag ID detected by the reader. The RFID reader is connected to the PC and interface base (Serial Port) that converted using USB converter as Figure 2. Testing of the product is always done to ensure it can be used to meet the users. 


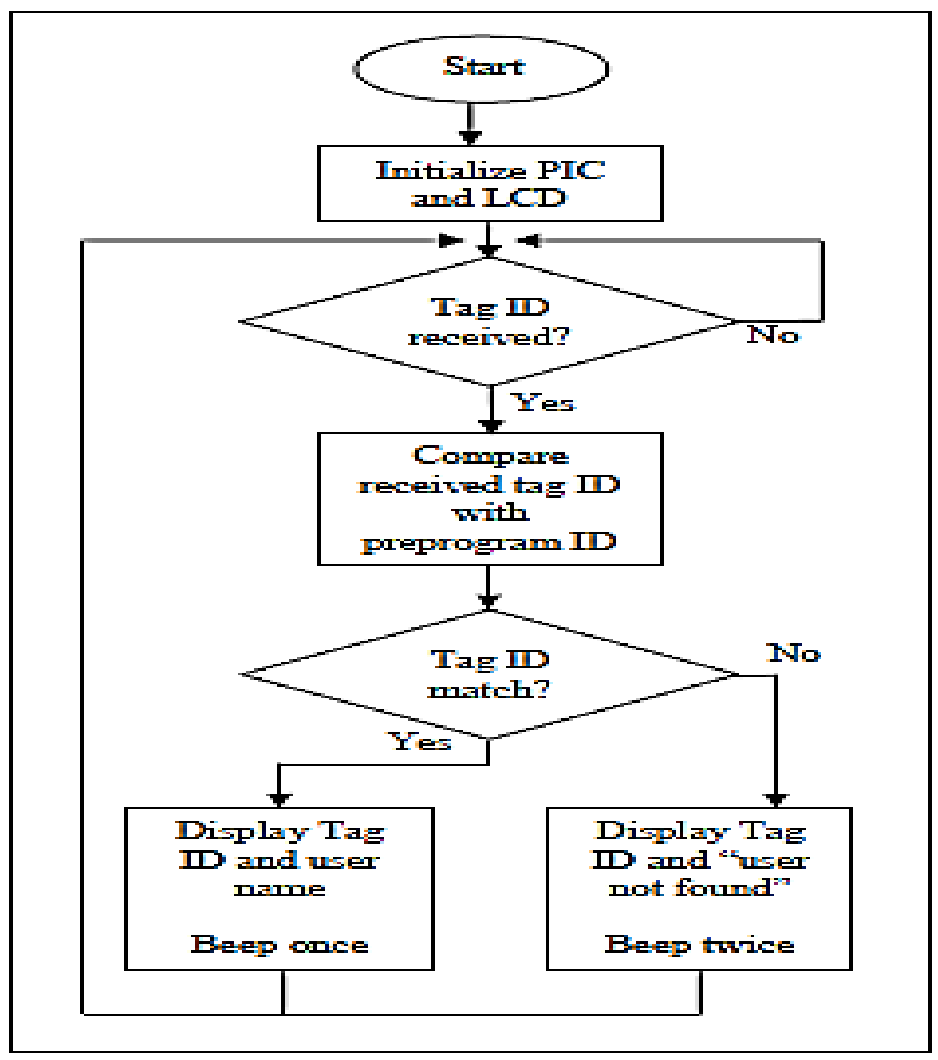

Figure 1 : Flow Chart of Design System

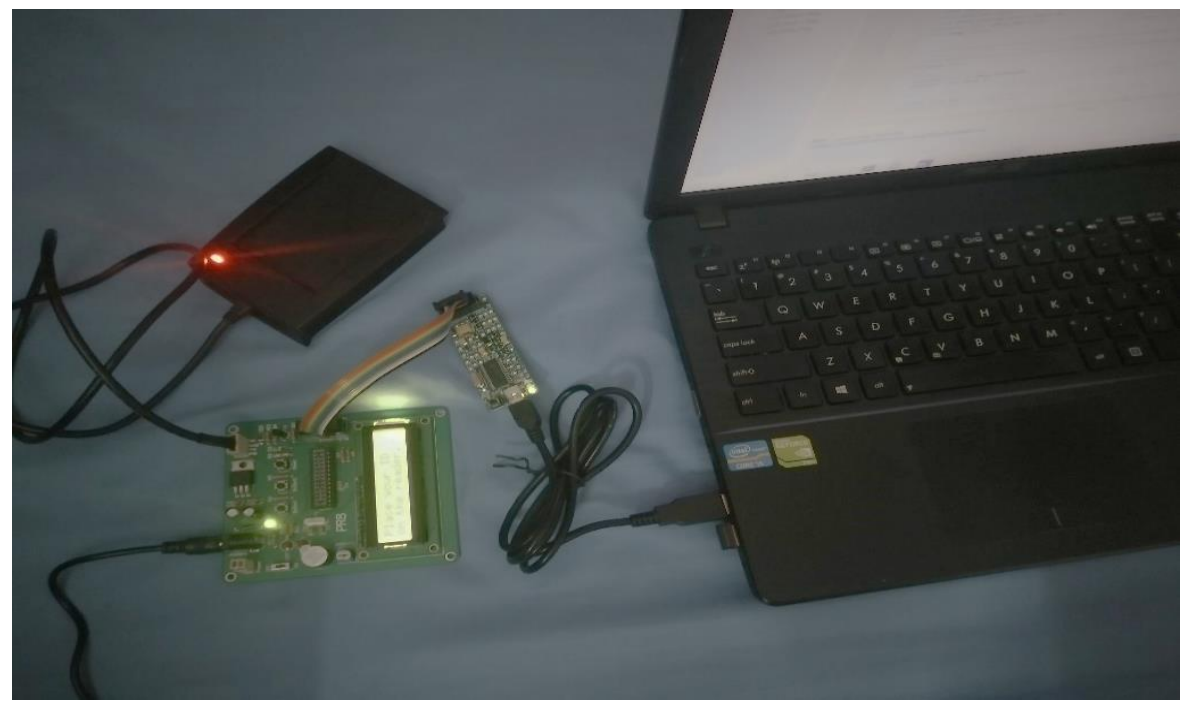

Figure 2: Connection to the PC

Purpose sampling was correlational studies minimum to obtain a good result is 30 respondents depends on the accuracy or desired error of the researcher and it was adopted from (Uma Sekaram, 2006). There were 30 randomly selected respondents as the questionnaire being distributed randomly to the staff UPSI as a respondents either at Kampus Sultan Abdul Jalil Shah (KSAJS) and Kampus Sultan Azlan Shah (KSAS). Data obtained was processed using Statistical Package for the 
INTERNATIONAL JOURNAL OF ACADEMIC RESEARCH IN BUSINESS AND SOCIAL SCIENCES Vol. 8, No. 7, July 2018, E-ISSN: 2222-6990 (C) 2018 HRMARS

Social Sciences (SPSS) to analyses for demography and variable such as frequency, mean, percentage and standard deviation.

\section{Result and Discussion}

There was 30 respondents of various backgrounds providing feedback on the questionnaire that have been given for project "Drive Thru" attendance system for staff Universiti Pendidikan Sultan Idris (UPSI) by using Radio Frequency Identification (RFID). Based on Table 1 it shows that 26 of the respondents (86.7\%) knows about the Radio Frequency Identification (RFID) meanwhile 4 of the respondents (13.3\%) does not know about the Radio Frequency Identification (RFID).

Table 1: Have you ever heard about the Radio Frequency Identification (RFID)?

\begin{tabular}{|c|c|c|c|c|c|}
\hline & & Frequency & Percent & Valid Percent & $\begin{array}{c}\text { Cumulative } \\
\text { Percent }\end{array}$ \\
\hline \multirow[t]{3}{*}{ Valid } & Yes & 26 & 86.7 & 86.7 & 86.7 \\
\hline & No & 4 & 13.3 & 13.3 & 100.0 \\
\hline & Total & 30 & 100.0 & 100.0 & \\
\hline
\end{tabular}

Among all of the questions, the statement of "Drive Thru" attendance system make staff like easier had the highest mean with 3.93 and follow with statement it enhance the quality time to manage as staff do not need to find the parking first for punch card with mean 3.90 as shown in Table 2 and Table 3 respectively.

Table 2: The "Drive Thru" method is much easier and interested.

\begin{tabular}{|c|c|c|c|c|c|c|}
\hline & & Frequency & Percent & Valid Percent & $\begin{array}{c}\text { Cumulative } \\
\text { Percent }\end{array}$ & Mean \\
\hline \multirow[t]{5}{*}{ Valid } & Disagree & 2 & 6.7 & 6.7 & 6.7 & \multirow{5}{*}{3.93} \\
\hline & Undecided & 5 & 16.7 & 16.7 & 23.3 & \\
\hline & Agree & 16 & 53.3 & 53.3 & 76.7 & \\
\hline & Strongly Agree & 7 & 23.3 & 23.3 & 100.0 & \\
\hline & Total & 30 & 100.0 & 100.0 & & \\
\hline
\end{tabular}


INTERNATIONAL JOURNAL OF ACADEMIC RESEARCH IN BUSINESS AND SOCIAL SCIENCES Vol. 8, No. 7, July 2018, E-ISSN: 2222-6990 @ 2018 HRMARS

Table 3: It enhance the quality time to manage as the staff do not need to find the parking first for punch card.

\begin{tabular}{|c|c|c|c|c|c|c|}
\hline & & Frequency & Percent & Valid Percent & $\begin{array}{c}\text { Cumulative } \\
\text { Percent }\end{array}$ & Mean \\
\hline \multirow[t]{5}{*}{ Valid } & Disagree & 5 & 16.7 & 16.7 & 16.7 & \multirow{5}{*}{3.90} \\
\hline & Undecided & 2 & 6.7 & 6.7 & 23.3 & \\
\hline & Agree & 14 & 46.7 & 46.7 & 70.0 & \\
\hline & Strongly Agree & 9 & 30.0 & 30.0 & 100.0 & \\
\hline & Total & 30 & 100.0 & 100.0 & & \\
\hline
\end{tabular}

Table 4 shows the question of RFID is suitable to be put at the one of the side corner such as at ELearning and museum UPSI of Kampus Sultan Abdul Jalil Shah (KSAJS) and security guard at campus Sultan Azlan Shah (KSAS) had the least mean 3.57 which shows that it need additional places of RFID zone. This can conclude that the higher the mean, the greater the distribution of the data.

Table 4: RFID is suitable to be put at the one of the side corner such as at ELearning and museum UPSI of Kampus Sultan Abdul Jalil Shah (KSAJS) and security guard at campus Sultan Azlan Shah (KSAS).

\begin{tabular}{|l|r|r|r|r|c|}
\hline & Frequency & Percent & Valid Percent & $\begin{array}{c}\text { Cumulative } \\
\text { Percent }\end{array}$ & Mean \\
\hline Valid Strongly Disagree & 1 & 3.3 & 3.3 & 3.3 & \\
Disagree & 5 & 16.7 & 16.7 & 20.0 & \\
Undecided & 5 & 16.7 & 16.7 & 36.7 & 3.57 \\
Agree & 14 & 46.7 & 46.7 & 83.3 & \\
Strongly Agree & 5 & 16.7 & 16.7 & 100.0 & \\
Total & 30 & 100.0 & 100.0 & & \\
\hline
\end{tabular}

Table 5 shows the lowest mean was 2.77 with the current attendance system take a lot of time to mark the attendance. This indicate respondents were not agree with this statement cause they thought it's functional the same as current system. In overall, the findings of the analysis have received positive responses from the respondents about project of "Drive Thru" attendance system for staff UPSI by using Radio Frequency Identification (RFID). They though with this project it's manage the time properly to arrive punctually and capable to eliminate time waste. 
INTERNATIONAL JOURNAL OF ACADEMIC RESEARCH IN BUSINESS AND SOCIAL SCIENCES Vol. 8, No. 7, July 2018, E-ISSN: 2222-6990 @ 2018 HRMARS

Table 5: The current attendance system take a lot of time to mark the attendance.

\begin{tabular}{|c|c|c|c|c|c|c|}
\hline & & Frequency & Percent & Valid Percent & $\begin{array}{c}\text { Cumulative } \\
\text { Percent }\end{array}$ & Mean \\
\hline \multirow[t]{6}{*}{ Valid } & Strongly Disagree & 4 & 13.3 & 13.3 & 13.3 & \multirow{6}{*}{2.77} \\
\hline & Disagree & 9 & 30.0 & 30.0 & 43.3 & \\
\hline & Undecided & 8 & 26.7 & 26.7 & 70.0 & \\
\hline & Agree & 8 & 26.7 & 26.7 & 96.7 & \\
\hline & Strongly Agree & 1 & 3.3 & 3.3 & 100.0 & \\
\hline & Total & 30 & 100.0 & 100.0 & & \\
\hline
\end{tabular}

\section{Conclusion}

The project of "Drive Thru" attendance system for staff UPSI by using RFID have achieved as stated objectives as researcher set and it's completed within specific time. The acceptance level of the respondents on this project "Drive Thru" attendance system for staff UPSI by using RFID is well received based on respondents' responses in the questionnaire that being analyzed. There are some aspects that can still be improved in the future. Overall, the respondents are satisfied and thought that it will improve the performance of their attendance.

Respondents do state the weakness for having the "drive-thru" attendance system for staff Universiti Pendidikan Sultan Idris (UPSI) by using Radio Frequency Identification (RFID) which is firstly, cost. Respondents argued that the cost of the product which the hardware and software must be considered during implementation around the Universiti Pendidikan Sultan Idris (UPSI) would cost a lot. The RFID tag for the staff, RFID reader, server and maintenance would increase compared to the current system. Data management will me mixed with current data which are not practical and would increase the cost to repair it.

Secondly, few of the respondents does not agree with this project because they thought that the traffic would become worst as the new attendance system only places at 3 locations only and should place more such as at Bitarasiswa and SITC hall. Respondents thought that it is not practical and only will give difficulty to monitor staff attendance.

Thus, improvement aspects must be done to improve the quality of the "Drive Thru" attendance system for staff UPSI by using RFID which is improvements in terms of research instruments. For this study, researcher used questionnaire as medium to see the effectiveness of the project "Drive Thru" attendance system for staff UPSI by using RFID. In the future, researcher may use others method or instruments such as interview with respondents for more accurate information which can be authentic information.

Besides, the development system can be improve and upgraded in the future with extending a new features or offer further enhancement such as long range contactless access control system to monitor staff attendance record which are functional like smart tag that would increase the efficiency of the attendance of the staff UPSI.

In a conclusion, the "Drive Thru" attendance system for staff Universiti Pendidikan Sultan Idris (UPSI) have successfully achieve the objectives and answered the previous speculation. This project is able to improve the old attendance system for staff Universiti Pendidikan Sultan idris (UPSI). With this system, the delayed issue can be reduced and to enhanced Universiti Pendidikan Sultan idris (UPSI) staff performance. 
INTERNATIONAL JOURNAL OF ACADEMIC RESEARCH IN BUSINESS AND SOCIAL SCIENCES

Vol. 8, No. 7, July 2018, E-ISSN: 2222-6990 (C) 2018 HRMARS

\section{Corresponding Author}

Abu Bakar Ibrahim, Universiti Pendidikan Sultan Idris, Malaysia, Tanjung Malim, Perak Malaysia.

Email: abupsp@gmail.com

\section{Acknowledgement}

I would like to take this opportunity to thank the Research Management \& Innovation Centre (RIMC) of Sultan Idris Education University for Permitting and Supporting in this research (2017-

0122-104-01)

\section{References}

Olanipekun, A.A., Boyinbode O.K. (2016), A RFID Based Automatic Attendance System in Educational Institution of Nigeria. International Journal of Smart Home, Vol 9(12), 1- 10. Abhijit, K., Jyoti, B. (2016), Embedded Web Server Based Management and Monitoring for Educational Institute: A Survey. International Journal of Innovation Research in Science, Engineering and Technology, Vol 5(1), 1-6. Arulogan, O.T., Olatunbosun, A., Fakolujo, O.A, Olaniya, O.M. (2013), RFID Based Students Attendance Management System. International Journal of Scientific \& Engineering Research, Vol 4(2), 1-9.

Nayak, B. B. (2015), RFID Based Attendance Management System using Labview. India: Department of Electronics \& Communication Engineering.

Chiagozie G. O., Nwaji G. O. (2012), Radio Frequency Identification (RFID) Based Attendance System With Automatic Door Unit. Academic Research Journal, Vol 2(2), 1-16.

Farhan M. N., Nivash S., Chandran, M. A. \& Chandran, M. A. (2016), Interior Tracking with Automatic Attendance and Reporting System. Indian Journal of Science and Technology, Vol 9(30), 1-5.

Arobi, H. B. (2011), In-Vehicle Signing System Using FRID (Master's thesis, Universiti Teknikal Malayisa Melaka, Malaysia).

Krenare, R., Pireva, J. S., Shkelqim, B. (2013), RFID: Management System for

Attendance. $15^{\text {th }}$ Workshop on International Stability, Technology, and Culture the International Federation of Automatic Control, Vol 8, 3-4.

Jiang, L. \& Li, Y. (2012), Attendance Technology on Campus Research and Application. National Conference on Information Technology and Computer Science (CITCS), 40-42.

Ayu, M. A., Barroon, I. A. (2014), TouchIn: An NFC Supported Attendance System in a University Environment. International Journal of Information and Educational Technology, Vol 4(5), 1.

Tunin, M. N. (2016), Intelligent Trace Attendance System (I-TAS) (Undergraduate's thesis, Universiti Teknologi Malaysia, Malaysia).

Saparkhojayev, N., Guvercin, S. (2012), Attendance Control System based on RFID Technology. IJCSI International Journal of Computer Science, Vol 9(1), 1-4.

Priyanka Sahare, P. G., Narule, S., Thakre, N., Chandekar, P. (2015), $\quad$ RFID Technology Based Attendance Management System. International Journal of Engineering and Computer Science, Vol 6(3), 1-6. 